BOOK REVIEW

\author{
AFRICAN UNION LAW: THE EMERGENCE OF A \\ SUI GENERIS LEGAL ORDER \\ WRITTEN BY OLUFEMI AMAO \\ ROUTLEDGE (LONDON AND NEW YORK) ISBN: 978- \\ 1-138-91494-0 (HBK), 978-1-315-69055-1 (EBK)
}

\author{
Reviewed by
}

\title{
Robert Home*
}

DOI: https://dx.doi.org/10.4314/jsdlp.v10i2.10

The African Union (AU), since its Constitutive Act in 2000, has grown from an initial 27 member states to now include all 55 countries on the African continent. The initiative came from the late President Gaddafi of Libya - an "unlikely figure", according to Amao, p. 16 - who called for Africa to create a robust international body at an "extraordinary summit" of the former Organization for African Union (OAU), held in his home town of Sirte in 1999. The last state to join, or rather rejoin - since it had split from the former OAU - was Morocco, in 2017.

The book's subtitle claims the AU as an emerging sui generis (or unique) legal order. That argument deserves further examination, perhaps more than Amao gives it. He explores the distinctive sources of AU law from the former OAU, yet the AU is not the only regional supranational legal order: one could mention the Association of Southeast Asian Nations

* Robert Home, MA PhD MRTPI Emeritus Professor in Land Management, Anglia Ruskin University (UK). Email Robert.home@anglia.ac.uk. 
(ASEAN), with its charter dating from 2007. Even within Africa, the Economic Community of West African States (ECOWAS). which comprises 15 countries with 350 million inhabitants and a land area larger than that of the European Union (EU), acts as an AU "regional mechanism", and has its own Court of Justice.

The AU can certainly claim to be the only continent-wide legal order, with member states covering the whole territory of the continent, as well as some offshore island states. It has a distinct geographical identity, surrounded by large seas on three sides; this contrasts with the EU to the north, with its uncertain geopolitical boundaries on its eastern side, and the Brexit potential for the United Kingdom (UK) to crash out. Whether AU membership criteria should be limited by geography or heritage remains unresolved. It maintains a Diaspora Division for people of African descent outside the continent, but the Caribbean state of Haiti, in spite of having a higher proportion of citizens of African origin than some AU member states, was declared non-admissible for associate membership rather than observer status to the $\mathrm{AU}$, as Amao discusses (p. 50).

Amao attempts to identify a distinctive nature of African law, based upon such principles as natural justice, community and group concerns, reconciliation, and belief in the super-natural, which he calls a "recognized universal system of principles running through African legal systems". The AU's "Solemn Declaration" (made to mark the 50th Anniversary of the OAU/AU in 2013) included certain arguably sui generis aspirations or concepts: "African solutions to African problems", "African Renaissance", "Pan-Africanism", "struggle against colonialism", and "a conflict-free Africa". ${ }^{1}$ In his chapter on customs and morality (particularly the case of sexual orientation), Amao discusses the "daunting" task of making progress in sensitive areas, and the AU declared commitment to greater gender equality is proving incompatible with deep-rooted patriarchal cultures.

The concept of institutional isomorphism rather contradicts the sui generis claim. Isomorphism has been applied from mathematics to organizational theory, identifying a similarity of processes or structure between organizations, as a result of independent development under

1 Solemn Declaration on the 50th Anniversary of the OAU/AU (2013) AU/Decl.3 XXI, Addis Ababa. 
similar constraints or imitation. ${ }^{2}$ Supranational bodies like the AU can be seen as organizations that are constructed and propagated through global cultural and associational processes. The 17 Sustainable Development Goals (SDGs) in the UN 2030 Agenda for Sustainable Development are a product of such processes, effectively setting a template for states and supranational bodies to follow. ${ }^{3}$ The SDGs emphasize legal institutional forms that maintain both state power and individual rights (the rule of law), and incorporate such matters as adherence to democratic norms, development-oriented economic and environmental policies, and mass schooling systems.

The strongest claim to a sui generis AU legal order comes in the area of human rights, which nearly half of Amao's book addresses through an analysis of AU jurisprudence. The AU is not unique in having a human rights court that tries to hold member states accountable for violations; other examples are the Inter-American Commission and Court of Human Rights, and the European Human Rights Court. ${ }^{4}$ The African Court of Human and Political Rights is the only operational judicial organ of the $\mathrm{AU}$, since proposals for putting it into a restructured AU Court of Justice are not yet ratified by member states. Behind the court is the African human rights charter (the Banjul Charter, unanimously approved by the OAU in 1981)..$^{5}$ This included universally accepted civil and political rights, but also places more emphasis than elsewhere upon economic, social and cultural rights, and upon group, collective or composite rights. The African court's judgments have adopted an expansive approach in some areas, as Amao discusses, and the AU has adopted legal instruments intended to protect women, children, youth, and displaced people, although their impact has been limited.

The expansive approach of its human rights court to group or collective human rights is taking the AU into uncharted waters, and indeed the main alternative text to Amao's book goes so far as to ask the

2 DiMaggio, P. \& Powell, W. 1983 "The Iron Cage Revisited: Institutional Isomorphism and Collective Rationality in Organizational Fields" American Sociological Review 48: 137-160.

3 Available on www.un.org/sustainabledevelopment/development-agenda.

4 Evans, MD \& Murray, RH (eds.) The African Charter on Human and Peoples' Rights: The System in Practice 1986-2006, Cambridge University Press, 2008.

5 African (Banjul) Charter on Human and Peoples' Rights. OAU Doc. CAB/LEG/ $67 / 3$. 
question: "Is the African Charter Fundamentally Flawed?" 6 Peoples' right to development (article 22 of the Banjul Charter) is one collective right that is generating debate, not least because of AU states' failures as its "duty-bearers". 7 "Peoples" were not explicitly defined in the charter, which is especially difficult in a continent with so many ethnic groups and racial/ethnic mixtures, as well as a legacy of decolonization. Peoples are, however, guaranteed a right to self-determination (article 20), which was historically important in the decolonization struggle, although the legacy of that struggle still raises difficult issues such as reparations. The UN Declaration on Rights of Indigenous Peoples in 2008 has subsequently caused controversy, with the African court supporting such rights, linked to Banjul Charter articles, in the Endorois and other judgments. ${ }^{8}$ Opposition of many AU member states to the concept of distinct groups of indigenous peoples has been manifested in tension between nomadic and sedentary cultures, a cause of conflict not only in Africa but also an issue of policy and human rights in the EU and UK for Gypsy/Traveller minority groups. ${ }^{9}$

The AU largely came into existence to prevent and manage interstate and civil conflict, in the aftermath of conflicts such as Somalia after 1991 and the Rwandan genocide of 1994. Its constitutive act can claim to be the first treaty under international law that gives it a right of military intervention for humanitarian reasons - sui generis? - and led to its distinctive African Peace and Security Architecture. Such conflicts remain frequent and intractable, exacerbated by the huge challenges of climate change and population growth. AU members feature prominently in international indices of fragile and failing states. The AU's ambitions are hampered by a high level of non-compliance with member state obligations, and weak sanctions against states jealous of their own sovereignty, making for "one of the biggest challenges that undermines

6 Magliveras, K.D. \& G.J.Naldi, 2018. The African Union (AU) Wolters Kluwer, p. 240.

7 Ngang, C.C., Kamga, S.D., Gumede, V. 2018 Perspectives on the right to development Pretoria University Law Press.

8 Complaint No. 276 / 2003: Centre for Minority Rights Development (Kenya) and Minority Rights Group International on behalf of Endorois Welfare Council v Kenya (decision endorsed by the AU Assembly in 2010).

9 Home, R.K. (2009) "Gypsies and Travellers in the United Kingdom: Planning, Housing and Human Rights in a Changing Legal Regulatory Framework" Stellenbosch Law Review 20(3): 533-50. 
the legitimacy of AU legal order", as Amao bluntly puts it (p. 165) and as other legal scholars have observed. ${ }^{10}$

Supranational legal orders are struggling everywhere. The AU may be moving towards an EU-style community in structure and processes, yet the EU itself is threatened by nationalist revivals, funding and structural problems. The Kagame report on AU restructuring (unfortunately coming too late to be fully discussed by Amao) is meeting strong objections over lack of consultation, and member states pushing back on the proposed levy.

In spite of these difficulties, the AU's "legal order" is here to stay. Amao's well organized and elegantly written book offers a welcome addition to the existing literature and can be expected to stimulate further research and critical legal scholarship. The AU's Commission on International Law "operates on the AU fringes and does not have a mainstream role" (Magliveras and Naldi, p.218), and African universities have been slow to introduce courses on AU law, although a new graduate programme on "Law and Politics of AU" is starting up in Tunisia. (That programme's location at the University of Carthage seems strangely appropriate to a sui generis argument, since ancient Carthage was the African enemy of the Roman empire that laid the foundation for a European legal order.) Femi Amao has been co-ordinating an African Union Law Research Network, one of eleven networks funded by UK research councils as part of the UN Decade on Peoples of African Descent, and an edited book of contributions on AU law is the next step for that network. ${ }^{11}$ Such endeavours can produce and transmit knowledge in an area that will surely grow in importance.

10 C. Okoloise "Circumventing Obstacles to the Implementation of Recommendations by the African Commission on Human and Peoples' Rights" (2018) African Human Rights Law Journal 18 27-57; CM Fombad "An Overview of the Crisis of the Rule of Law in Africa" (2018) African Human Rights Law Journal 18 213-243. 